\title{
Was Tropical Cyclone Heta or Hunting by People Responsible for Decline of the Lupe (Ducula pacifica) (Aves: Columbidae) Population on Niue during 1994-2004? ${ }^{1}$
}

\author{
R. G. Powlesland, ${ }^{2}$ D. F. Butler, ${ }^{3}$ and I. M. Westbrooke 4
}

\begin{abstract}
On 6 January 2004, Tropical Cyclone Heta devastated much of the South Pacific island nation of Niue. The forest suffered extensive damage, particularly to the north-western sector, with many trees uprooted and others stripped of branches and foliage. Even though some patches of forest in the southeast sustained little damage, many lupe (Pacific pigeon, Ducula pacifica) and kulukulu (purple-crowned fruit dove, Ptilinopus porphyraceus) entered eastern villages in search of food and water after the cyclone, a very unusual behavior. This paper details our findings from a survey of some of Niue's forest birds carried out during September 2004 and compares these with results from a similar survey in September 1994. Five-minute point count data, an index of conspicuousness, from three transects showed that heahea (Polynesian triller, Lalage maculosa) were more abundant in 2004 than in 1994, that the results were variable from transect to transect for miti (Polynesian starling, Aplonis tabuensis) and kulukulu, but that significantly fewer lupe were detected along all three transects in 2004 than previously. We tentatively suggest that the decline in the lupe population was caused mainly by unsustainable human hunting during 1994-2004, rather than mortality caused by the cyclone.
\end{abstract}

Tropical Cyclones and hurricanes can cause severe damage to forests, resulting in the stripping of leaves, flowers, fruits and seeds; breaking of trunks and branches; and toppling of trees (Wiley and Wunderle 1993, Bellingham et al. 1994, Everham and Brokaw 1996, Burslem et al. 2000). The im-

${ }^{1}$ This work was approved by the Government of Niue and funded by the United Nations Development Programme via its "Enabling Activity on Biodiversity" project, and the New Zealand Department of Conservation (Science Investigation no. 3779). Manuscript accepted 7 December 2007.

2 Corresponding author: Research, Development, and Improvement Division, Department of Conservation, P.O. Box 10-420, Wellington 6143, New Zealand (e-mail: rpowlesland@doc.govt.nz).

${ }^{3}$ David Butler Associates Ltd., 588 Brook Street, Nelson 7010, New Zealand.

${ }^{4}$ Research, Development, and Improvement Division, Department of Conservation, P.O. Box 13-049, Christchurch 8141, New Zealand.

Pacific Science (2008), vol. 62, no. 4:461-471

(C) 2008 by University of Hawai'i Press

All rights reserved pact of such storms can be quite variable on both forests and birds. For example, areas of undamaged forest in gullies and valleys can occur within $200 \mathrm{~m}$ of areas where many trees on exposed ridges and hills have been toppled and those still standing have been stripped of foliage (Varty 1991, Wunderle 1995, 1999, Robertson and Saul 2007). High winds and heavy rainfall associated with cyclones and hurricanes can kill birds, but studies have shown that it is the indirect effects of such storms that usually have the most profound and long-lasting impacts on bird populations (Varty 1991, Wauer and Wunderle 1992, Wiley and Wunderle 1993, Wunderle 1995, Prather and Smith 2003, Tejeda-Cruz and Sutherland 2005, Robertson and Saul 2007). These effects include loss of food supplies, foraging substrates, and nest or roost sites and increased vulnerability to predation, including by people (Craig et al. 1994, Wunderle 1995). Before trees and shrubs have recovered, birds may respond by changing their diets, locations, habitats, and timing of breeding (Varty 1991, Wunderle et al. 1992, Wiley and Wunderle 1993, Wunderle 1995). In 
general, short-term studies have shown that population declines of nectarivorous, frugivorous, and granivorous species after such destructive storms are more prevalent than those of insectivorous and omnivorous species (Askins and Ewert 1991, Waide 1991, Wunderle et al. 1992, Wiley and Wunderle 1993, Wunderle 1995, Tejeda-Cruz and Sutherland 2005). This is to be expected given that flower and fruit production often does not eventuate for several months after a cyclone or hurricane (Wunderle et al. 1992), whereas some arthropod populations either are unaffected by such storms or have quick recovery rates (Wolcott 1932, Wiley and Wunderle 1993).

Tropical Cyclone Heta, henceforth referred to as Cyclone Heta, passed over the South Pacific island of Niue on 6 January 2004. During the cyclone, winds in excess of $270 \mathrm{~km} / \mathrm{hr}$ (winds equivalent to hurricane 3 strength) ravaged Niue for about $5 \mathrm{hr}$, and a mountainous storm surge battered the west coast. The main settlement, Alofi, and the villages of Makefu, Tuapa, Namukulu, and Hikutavake (Figure 1) were all seriously affected. The combination of a high spring tide, cyclone travel direction, wind velocity and spiral direction, and a sloping seabed combined to maximum effect to produce a sea surge estimated at $50 \mathrm{~m}$. This overtopped the cliffs and, in some areas pushed seawater $100 \mathrm{~m}$ inland, devastating everything in its path. In addition to the loss of human life and property that resulted, serious damage was done to Niue's forest, particularly on the northern and western sides of the island. If not blown over, most trees and shrubs were stripped of leaves, flowers, fruit, and thin branches, and subjected to salt spray. The cyclone was followed by several days of intense heat, with no rain. After the cyclone, some fires used to clear areas of land for gardens got out of control and destroyed forest because of the considerable volume of flammable material produced by the cyclone that remained on the ground (M. Newfield, pers. comm.).

Although Cyclone Heta and the drought that followed immediately afterward killed some wildlife, of more concern was the sur- vival of forest-dwelling species during the subsequent period of several months when few flowers and fruit were available. Species of concern included the peka (Tongan flying fox, Pteropus tonganus), lupe (Pacific pigeon, Ducula pacifica), kulukulu (purple-crowned fruit dove, Ptilinopus porphyraceus), miti (Polynesian starling, Aplonis tabuensis), and hega (blue-crowned lorry, Vini australis). In late January, sprouting of foliage on defoliated trees was evident, and reasonable numbers of most forest bird species were seen in lessaffected forest areas (Butler 2004). This allayed initial concerns for bird population survival. However, many peka, lupe, and kulukulu on the eastern side of the island entered villages in search of food and water, a very atypical behavior. In response to what was obviously a crisis for the birdlife of Niue, the Government of Niue provided funds for a program, coordinated by Misa Kulatea, to provide food and water at feeding stations. In addition, because bats and birds entering villages were vulnerable to predation by dogs, cats, and people, some peka and lupe were taken into captivity, with the intention of releasing them once natural food sources became readily available again.

After his assessment of the impacts of Cyclone Heta in late January 2004 (Butler 2004), D.J.B. urged the Government of Niue to conduct more in-depth surveys of the flora and fauna. As a result, a survey of some of Niue's forest birds was carried out during 319 September 2004. This paper details the findings from the survey and compares the results with those from a survey in September 1994 using the same methodology (Powlesland et al. 2000).

\section{MATERIALS AND METHODS}

\section{Study Area}

Niue is an isolated, single, raised-coral atoll in the south-central Pacific $\left(19^{\circ} 03^{\prime} \mathrm{S}, 169^{\circ}\right.$ $\left.55^{\prime} \mathrm{W}\right)$. It is roughly circular (18 by $21 \mathrm{~km}$ [see Figure 1]), $261 \mathrm{~km}^{2}$ in area, and formed of two terraces (Powlesland et al. 2000). For details of the island's geological origin, soils, and vegetation cover, see Schofield (1959), 


\section{Niue}
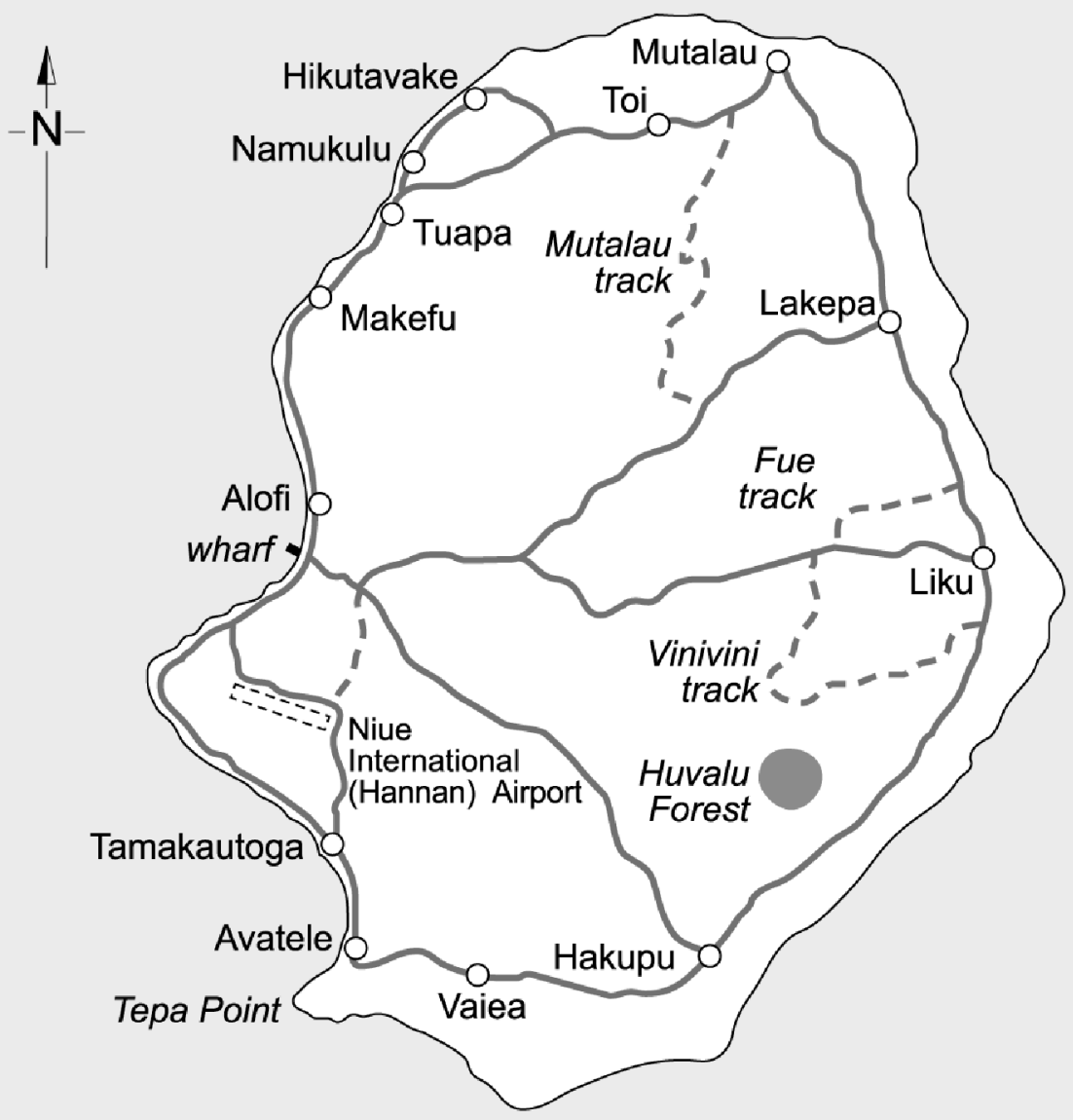

$19^{\circ} 00^{\prime} \mathrm{S}$

0

$5 \mathrm{~km}$

$169^{\circ} 55^{\prime}$

$169^{\circ} 50^{\prime} \mathrm{W}$

FIGURE 1. Niue Island, showing the locations of villages, sealed roads (solid lines), and the three tracks (dotted lines) along which the 5-min bird counts and rat trapping were carried out.

Lane (1994), and Martell et al. (1997), respectively. The island may have been inhabited by Polynesians for about 2,000 years (Walter and Anderson 1995), and the population was estimated at 1,769 people in 2001 (Richmond-Rex et al. 2001). The long-term conservation of Niue's flora and fauna depends, in part, on the continued presence of habitats that existed before people colonized the island (Richmond-Rex et al. 2001).

All but one species of bird, the introduced moa (feral fowl, Gallus gallus), would have flown to Niue, even if assisted by storm-force winds. All the species currently breeding on Niue are of western Polynesian origin, and most have originated from Tonga or Samoa. 
Although the heahea (Polynesian triller, $\mathrm{La}$ lage maculosa) and miti have evolved into distinct subspecies on Niue, all other species are found elsewhere in the Indo-Pacific region (Watling 2001). Niue has a variety of introduced mammals. Two species of rats are ubiquitous: the kuma or Pacific rat (Rattus exulans), introduced by the early Polynesian settlers, and the ship rat ( $R$. rattus), which arrived between 1902 and 1925 (Smith 1902, Wodzicki 1971). Mice (Mus musculus), dogs (Canis familiaris), and cats (Felis catus) are common around villages, and feral cats are widespread over the island. Escaped pigs (Sus scrofa) are present in some areas of forest.

\section{Five-Minute Bird Counts}

In both 1994 and 2004, index counts of forest birds were made using the 5 min point count technique (Dawson and Bull 1975), an index of "conspicuousness." Transects (nonrandomly selected) were along vehicle tracks through mature forest, regenerating scrub, and gardens under cultivation (mainly for taro). At the start of each field trip, the $200 \mathrm{~m}$ distance between successive points or count stations along the transects was measured with a tape measure, and the locations marked with flagging tape. At each station all birds seen or heard within a $100 \mathrm{~m}$ radius of the observer were noted during a $5 \mathrm{~min}$ period. The transects were at three places (see Figure 1). The Mutalau transect (20 count stations) ran north-south through the middle of the northern end of the island. It traversed small areas of taro gardens and remnant forest, and extensive areas of regenerating scrub. Because many trees along the Fue and Vinivini transects had been uprooted during Cyclone Heta and not cleared by September 2004, fewer count stations were available along these transects than in 1994. The Fue (14 stations) and Vinivini transects (16 stations) were mainly through mature forest and regenerating forest, with few garden plots being worked at the time. See Table 1 for a summary of the number of counts undertaken along each transect in September 1994 and 2004.

\section{Statistical Analyses}

When determining the difference in the counts for a species for a particular transect, the difference between 1994 and 2004 means at each station was taken. Only stations where counts were taken in both 1994 and 2004 were included. A $t$-test on the station differences for each transect was used to establish whether the mean difference was significantly different from zero. This is equivalent to a two-sided paired $t$-test for a difference between the means for 1994 and 2004. For each transect, the mean of the included stations means was calculated. Based on Johnson (1995), a $t$-test approach was seen as appropriate for comparing means, in particular means of these station means, in preference to nonparametric approaches. No adjustment for multiple comparisons was made, because each of four species on each of three transects was evaluated separately and all the results presented.

RESULTS

\section{Heahea}

During the September 2004 visit, heahea were vocal and territorial. Territorial disputes were frequent, involving much chasing and loud song. Many pairs were breeding, with adults regularly seen carrying invertebrate prey. One nest was found at which the adults were feeding large chicks, and many pairs were seen feeding one or two fledglings. Most heahea were seen foraging for invertebrates through the foliage in the scrub and forest canopies. In addition, a few birds were seen foraging on roads and lawns, presumably taking mainly invertebrates, although on one occasion a heahea was observed subduing a small skink.

A comparison of the index of abundance (conspicuousness) for heahea in September 1994 and September 2004 (Table 1), as determined by the 5 min count technique, indicates that there was little difference in abundance along the Mutalau transect. However, there were significantly more heahea in 
TABLE 1

A Comparison of 5-Min Counts of Heahea (Lalage maculosa), Miti (Aplonis tabuensis), Kulukulu (Ptilinopus porphyraceus), and Lupe (Ducula pacifica) in 1994 and 2004 for Each Transect, Niue Island

\begin{tabular}{|c|c|c|c|c|c|}
\hline \multirow[b]{2}{*}{ Parameter } & \multicolumn{2}{|c|}{ Mutalau } & \multicolumn{2}{|c|}{ Fue } & Vinivini \\
\hline & 1994 & 2004 & 1994 & 2004 & $1994 \quad 2004$ \\
\hline No. of stations & \multicolumn{2}{|c|}{20} & \multicolumn{2}{|c|}{14} & 16 \\
\hline No. of counts & 139 & 160 & 117 & 160 & $128 \quad 154$ \\
\hline \multicolumn{6}{|l|}{ Heahea } \\
\hline Mean no. ${ }^{a}$ & 3.4 & 3.6 & 2.5 & 3.3 & 4.1 \\
\hline SE & \multicolumn{2}{|c|}{0.145} & \multicolumn{2}{|c|}{0.214} & 0.180 \\
\hline$t$-statistic & \multicolumn{2}{|c|}{1.367} & \multicolumn{2}{|c|}{3.776} & 7.288 \\
\hline$P$ value & \multicolumn{2}{|c|}{$P=.188$} & \multicolumn{2}{|c|}{$P=.002$} & $P<.001$ \\
\hline \multicolumn{6}{|l|}{ Miti } \\
\hline Mean no. ${ }^{a}$ & 2.6 & 2.0 & 2.3 & 2.3 & 2.6 \\
\hline $\mathrm{SE}$ & \multicolumn{2}{|c|}{0.298} & \multicolumn{2}{|c|}{0.225} & 0.283 \\
\hline$t$-statistic & \multicolumn{2}{|c|}{2.0930} & \multicolumn{2}{|c|}{0.047} & \multirow{2}{*}{$\begin{array}{c}1.271 \\
P=.223\end{array}$} \\
\hline$P$ value & \multicolumn{2}{|c|}{$P=.050$} & \multicolumn{2}{|c|}{$P=.963$} & \\
\hline \multicolumn{6}{|l|}{ Kulukulu } \\
\hline Mean no. ${ }^{a}$ & & 1.3 & 1.1 & 1.3 & 1.9 \\
\hline SE & \multicolumn{2}{|c|}{0.241} & \multicolumn{2}{|c|}{0.164} & 0.182 \\
\hline$t$-statistic & \multicolumn{2}{|c|}{7.407} & \multicolumn{2}{|c|}{1.29} & 4.305 \\
\hline$P$ value & $P<$ & .001 & $P=$ & .219 & $P<.001$ \\
\hline Lupe & & & & & \\
\hline Mean no. ${ }^{a}$ & 1.5 & 0.9 & 2.0 & 1.5 & 2.4 \\
\hline SE & & 78 & & & 0.232 \\
\hline$t$-statistic & & 91 & 2. & & 6.637 \\
\hline$P$ value & $P=$ & .003 & $P=$ & .018 & $P<.001$ \\
\hline
\end{tabular}

Note: Only stations counted in both years are included, although 20 stations were counted on each transect in 1994. The standard error (SE), $t$-statistic, and $P$-value are based on a twosided paired $t$-test for difference between the two years, based on the average station counts in each year.

${ }^{a}$ Mean number of birds per 5-min count.

2004 than in 1994 along the Fue $(P<.05)$ and Vinivini transects $(P<.01)$.

\section{Miti}

As in 1994, miti in 2004 were widespread over Niue wherever forest was present. Occasional miti were seen visiting nest cavities, but it was not obvious whether incubation or brood rearing was occurring. However, several pairs were accompanied by food-begging fledglings.

There were significantly fewer miti along the Mutalau transect in 2004 than in 1994 $(P<.05)$ (Table 1). However, the mean number of miti detected per count was not significantly different for the Fue and Vinivini transects between the two years.

\section{Kulukulu}

Kulukulu were widespread in forested areas of Niue in September 2004, mainly evident by their distinctive and loud calls. The regular, loud calling of kulukulu (males calling to attract mates and to indicate territory occupancy to other males [Gibbs et al. 2001]) suggested that breeding was under way, but no nests were found, and only one recent fledgling was seen.

The results of comparisons of the 5-min counts from 1994 and 2004 for kulukulu along the three transects were variable (Table 1). There was no significant difference for the Fue transect, significantly more kulukulu were detected along the Vinivini transect in $2004(P<.001)$, and significantly fewer were detected along the Mutalau transect in $2004(P<.001)$.

\section{Lupe}

A flock of lupe, consisting of a few hundred birds, fed in low scrub around the airport after the cyclone. They had not been seen feeding at this location just before the cyclone or in previous years. Several were found dead in the area. No specimens were submitted for necropsy or toxin testing, but because the lupe were thought to have been feeding on green berries of lantana (Lantana camara), which are known to be toxic to mammals (Shepherd 2004), it was suggested by locals that the lupe may have been poisoned by toxin in the berries.

During the survey in September 2004, lupe were seen and/or heard wherever tall, diverse forest was present. Neither occupied nests were found nor recent fledglings seen. However, it is probable that some lupe were nesting, given the frequent calling by both sexes (especially males), the occasional display flight, and the fruiting of a variety of tree species.

The mean number of lupe detected along each of the transects was significantly fewer 
in 2004 than in 1994 (Table 1). The decline varied from $28 \%$ for the Fue transect to $64 \%$ for the Vinivini transect.

\section{DISCUSSION}

\section{Interpretation of Results}

Ideally, determining the impact of Cyclone Heta on forest bird populations of Niue would have involved observations a few weeks before the cyclone, and then observations repeated a couple of months after the cyclone once foliage and rainwater were available. Our observations following the cyclone, although 8 months afterward, were carried out in September 2004 so that they were during the same month as the only previous observations of Niue's forest birds using the same methodology, September 1994. Because we compare our postcyclone observations with those obtained nearly $10 \mathrm{yr}$ previously, our interpretation of why changes in bird species population abundance occurred must be tentative.

\section{Heabea}

The 5-min counts indicated that heahea were more abundant in September 2004 than in September 1994 along the Fue and Vinivini transects, but not the Mutalau transect. Either Cyclone Heta had little impact on the heahea population of Niue, with surviving heahea moving from damaged (Mutalau) to less-damaged areas (Fue and Vinivini), as noted for some species in hurricane-affected forests (Wunderle et al. 1992), or heahea bred well after the cyclone and more than made up for any losses. Given the strength of the winds that tore most foliage and twigs from trees over more than $50 \%$ of the island, it is likely that some heahea were killed during the storm. After the cyclone, probably a few weeks elapsed before invertebrate prey populations would have begun to recover, especially the arboreal species that heahea mainly feeds upon in forest and scrub habitats. Whether the heahea population declined further during that time is not known, but from observations 3 weeks after the cyclone,
Butler (2004) considered that the heahea population had declined markedly. The rapid population recovery within 8 months seems plausible given that the heahea is a habitat generalist throughout its range (Steadman and Freifeld 1998, Steadman and Franklin 2000, Watling 2001) and has varied foraging habits (arboreally in forest and scrub habitats, on the ground in open habitats), and a varied diet (invertebrates, small reptiles, and fruit) (Watling 2001). The resprouting of the defoliated trees, already evident within 3 weeks of the cyclone (Butler 2004), would have stimulated some invertebrate species to breed. As an indication that this did occur, we found during our 2004 survey that butterflies were particularly evident along forest tracks and in coastal areas by day, and hundreds of moths and beetles were attracted to lights at night. Likewise, Torres (1992) reported outbreaks of 15 species of Lepidoptera on Puerto Rico as a result of the profusion of new foliage that developed after forest defoliation caused by Hurricane Hugo. Such aggregations of invertebrates on Niue were not seen during R.G.P.'s visits in 1994. Given that heahea feed extensively on arboreal invertebrates, especially caterpillars (Watling 2001; R.G.P., pers. obs.), and have a long breeding season (at least March to November [Powlesland et al. 2000, Watling 2001]), some pairs of heahea may have reared two or even three broods (one or two chicks per brood) during February-August 2004 as forest and scrub plants developed new foliage. Similarly, Lovegrove et al. (1992) found that the Polynesian triller in Western Samoa (Lalage $m$. maculosa) had increased at three of 11 sites within 3 months of the very destructive $\mathrm{Cy}$ clone $\mathrm{Val}$, but it was not known whether this was due to dispersal or breeding. The result for the heahea on Niue is consistent with those of previous studies indicating that insectivorous species may benefit from habitat disturbance caused by cyclones and hurricanes (Wunderle 1995, Tejeda-Cruz and Sutherland 2005). However, not all insectivorous bird populations benefit from such disturbances: the kakerori (Pomarea dimidiata) population on Rarotonga survived five cyclones during a 4-week period in 2005 well, 
but the main effect on the population was not evident until the following breeding season when nesting success was exceptionally poor because the greatly reduced canopy cover meant that many nests were exposed to abnormally wet conditions (Robertson and Saul 2007).

\section{Miti}

Fewer miti were evident along the Mutalau transect in September 2004 than in September 1994, but there were similar numbers along the other two transects during the two surveys. This geographic change in distribution of miti between the two surveys probably related to the variable impact of the cyclone on the forest from west to east (Butler 2004). Likewise, Lovegrove et al. (1992) found that the same species on Western Samoa had declined at four of 11 sites resurveyed 3 months after Cyclone Val. The result for miti on Niue may relate to the prominence of fruit in the miti's diet and the lesser impact of the cyclone on forest on the eastern side of the island. The Polynesian starling elsewhere in the Pacific tends to be a habitat generalist and increases in relative abundance with increasing maturity of forest (Steadman and Franklin 2000). It feeds mainly on fruit and eats some insects (Feare and Craig 1999, Watling 2001). How important fruit is in the diet of miti on Niue is not known. If fruit is important, especially for breeding, then the miti population would have been slower to recover from any decline associated with the cyclone than the heahea. First, there would be intense competition for any fruit remaining after a cyclone given that kulukulu, lupe, and peka all feed mainly on fruit. Second, although trees and shrubs can start sprouting foliage within a few weeks of being defoliated, the availability of flowers, and then fruit, would be several weeks, or perhaps even months, later (Wunderle et al. 1992, Wunderle 1999).

\section{Kulukulu}

As its English name (purple-capped fruit dove) implies, the kulukulu feeds predomi- nantly on small fruit (Steadman and Freifeld 1999, Gibbs et al. 2001, Watling 2001). However, there would have been few fruits available for kulukulu after the cyclone, particularly in the northwestern forests of Niue. After the cyclone, kulukulu were desperate for food, as evidenced by doves searching for food and water in villages, places where they are rarely seen foraging (M. Kulatea, pers. comm.; Freifeld 1999). Although kulukulu are not usually hunted by people these days, it is very likely that some doves, weakened by hunger and thirst in or near villages, would have fallen prey to cats and dogs. Presumably, the decline in abundance of kulukulu along the Mutalau transect and the increase along the Vinivini transect was because of movement of doves from the worst cyclone-affected forests in the west to those less affected in the east. Even though there were significantly fewer kulukulu present along the Mutalau transect in 2004 than in 1994, there were ample kulukulu still surviving over the island for the population to recover. As the forest recovers, fruit production is expected to return to normal, enabling kulukulu to breed. In addition, given the declining number of people on Niue in recent years (Richmond-Rex et al. 2001), the area of bush gardens left to regenerate is increasing, which may gradually result in an increased area of suitable habitat for forestinhabiting birds, such as kulukulu.

\section{Lupe}

Lupe were significantly less conspicuous along all three transects in September 2004 than in September 1994 (Table 1). Like kulukulu, lupe were seen searching for food and water in villages along the western side of Niue after Cyclone Heta. Because they are hunted, lupe are usually wary of people and avoid foraging in or near villages. This phenomenon of "acquired" shyness in hunted bird species has been observed on other $\mathrm{Pa}$ cific islands (Barrett and Freeman 1986). Likewise, the flock of several hundred lupe seen foraging in low scrub near the airport soon after the cyclone was unusual, as they generally inhabit diverse and relatively un- 
disturbed native forest (Freifeld 1999). Some birds were so weakened by lack of food that they were able to be caught by hand $(\mathrm{M}$. Kulatea and B. Pasisi, pers. comm.). Throughout the South Pacific region, fruit bat (Pteropus spp.) and pigeon (mainly Ducula spp.) hunting is part of the culture of indigenous peoples; these food sources are a traditional delicacy (Sinavaiana and Enright 1992). Therefore, we expect that people took advantage of this situation and harvested some lupe, as has happened elsewhere in such situations (Craig et al. 1994, Esselstyn et al. 2006), and other lupe were preyed upon by cats and dogs. Lupe numbers declined markedly in Samoa and American Samoa after cyclones in the early 1990s (Lovegrove et al. 1992; Watling 2001). However, we believe it is unlikely that the lupe mortality directly or indirectly caused by Cyclone Heta would have brought about the dramatic population decline on Niue evident from our 5-min counts.

Lupe feed mainly on fruit (Steadman and Freifeld 1999, Gibbs et al. 2001, Watling 2001), although they can probably subsist on leaf buds and shoots, and flower buds and flowers when fruit is in short supply (Watling 2001). Given that the lupe's diet is similar to that of the kulukulu, it is noteworthy that the lupe population had declined significantly along all three transects since 1994 (28-64\% per transect), whereas kulukulu abundance had declined significantly only along the $\mathrm{Mu}-$ talau transect, where the cyclone impact was greatest on the forest. An important difference is that the lupe is subject to cultural harvest (by shooting) and the kulukulu is not. There is keen interest in hunting lupe, both during the legal season (December-January annually, March too in recent years) and outside of it. We suspect that this is the main cause of the decline in the lupe population. From interviews with 13 hunters in September 2004, it transpired that these hunters had shot an average of 85 lupe each during December 2003 (A. Brooke and J. Talagi, pers. comm.). There were 425 shotguns registered in December 2003 on Niue, and each hunter was entitled to 100 cartridges per gun for the shooting season (M. Tongatule, acting police chief, pers. comm.). Although some car- tridges would have been fired at peka, a reasonable proportion would have been fired at lupe. Even if there were only 60 active hunters, the interviews suggest that they shot about 5,000 lupe in December 2003 (A. Brooke, pers. comm.).

To calculate the number of lupe on Niue and estimate the impact of 5,000 lupe being harvested annually, we assumed that about $33.5 \%$ or 8,755 ha of Niue's 26,173 ha was habitat suitable for lupe (coastal forest, mature tropical forest, and late-stage regenerating forest) (Martell et al. 1997), and that there were 2.55 lupe per hectare in September 2004 as determined from the figure of 1.1 per 5 -min count area of 3.14 ha (radius $100 \mathrm{~m}$ ), but with only $50 \%$ of the area being of suitable habitat, and that only $25 \%$ of lupe were seen or heard. This gives an estimated total of 22,325 lupe on Niue in September 2004. Thus a harvest of about 5,000 lupe from a population of about 30,000 in December 2003 is $16.7 \%$, a large proportion for a species to replace before the next year's hunting season, given that lupe lay just one egg per nest (Watling 2001). If our assumption of the proportion detected during the 5-min counts is too conservative (more than $25 \%$ are detected during counts), this would reduce the total population estimate and so indicate that the population is under greater threat from hunting than suggested here. Even if the hunters exaggerated their tallies of lupe harvested, say by as much as $50 \%$, then the proportion harvested would reduce to about $10 \%$. This is still a sizeable proportion of the population, given its low breeding rate and the likely severe predation of eggs and chicks by ship rats on Niue (James and Clout 1996).

Fruit-eating birds, such as lupe, kulukulu, and miti, and fruit bats (peka) are important seed dispersers, and so are important in the ecology of forests (Cox et al. 1991, Lee et al. 1991). Conservation of such keystone species is important because their loss may have major implications for ecosystems (Esselstyn et al. 2006). For example, there is evidence that fruit bats may disperse seeds widely only when bat density is sufficient to promote competition for fruit. Thus, when bat, and 
probably lupe, abundance is low they may not perform some of the ecosystem functions that give them keystone status (Richards 1990, Rainey et al. 1995, McConkey and Drake 2002). To ensure successful regeneration of the full complement of the Niuean forest flora throughout the island it is essential that fruit-eating birds and bats are fairly common and visit all forest patches. If these fruit-dispersing species become scarce, then the forests' ability to recover after cyclones and fires is likely to be compromised.

One way of assisting these species immediately after a cyclone when fruit sources are usually scarce is "life-lining" (Lovegrove et al. 1992). Life-lining is the provision of food supplements at food stations to birds and bats in the wild for a few weeks or months while water and/or natural foods are scarce. Lifelining eliminates the need to catch and handle essentially healthy wild birds and bats, build captive facilities, settle them into captivity, and then ensure that they are fit enough later to be released back into the wild. By his efforts Misa Kulatea showed that lupe and peka readily found and took advantage of supplementary foods. Once natural food sources again became available in the forest, several months after the cyclone, the birds and bats no longer visited the food stations, preferring instead to feed in the forests. Although life-lining concentrates birds and bats in a small area, exposing them to possible human hunting and predation by dogs and cats, these problems can be overcome. Certainly life-lining is preferable to maintaining lupe and peka in captivity, because the latter is invariably quite expensive, and much time spent in captivity can compromise individuals' ability to cope when released back into the wild.

\section{CONCLUSIONS}

Comparisons of 5-min counts (an index of conspicuousness) of forest birds at points along three transects in September 1994 and September 2004 on Niue, to assess the possible impact of Cyclone Heta in January 2004, provided differing results for the four species of interest. The most interesting results are those for kukukulu (dove) and lupe (pigeon), because both feed mainly on fruit and have a similar breeding rate (one egg per nest). Although kulukulu abundance in 2004 was significantly less than in 1994 only along the transect worst affected by the cyclone, lupe numbers were significantly less abundant along all three transects. The main difference between these two species is that the lupe is subject to an apparently intense cultural harvest regime and the kulukulu is not harvested. Thus, even though the precyclone population assessment is based on a survey nearly $10 \mathrm{yr}$ before Cyclone Heta occurred, we suspect that the marked decline in lupe numbers between the two surveys relates mainly to an unsustainable annual harvest. If the frequency of severe cyclones striking Niue increases in future, as predicted by some researchers (Trenberth 2005, Webster et al. 2005), then the recovery of the lupe population between cyclones would be compromised by its low population numbers and the unsustainable hunting. Thus, the Government of Niue should consider making the enforcement of lupe hunting laws a priority and continue to institute hunting bans after severe cyclones until monitoring indicates that the lupe population has recovered sufficiently.

\section{ACKNOWLEDGMENTS}

We thank Tagaloa Cooper and Judy Nemaia, Department of Environment, Niue, for arranging the logistics for our work and for arranging meetings with various Niueans; John Talagi and Haden Talagi, Department of Environment, for assistance with fieldwork; Misa Kulatea and Ioane Mamaia for information about the birdlife and the impact of $\mathrm{Cy}$ clone Heta and hunting on various Niuean species; Anne Brooke for assistance with fieldwork and information from her interviews; and the manuscript benefited from the constructive comments of Anne Brooke, Greg Sherley, Hugh Robertson, and two referees.

\section{Literature Cited}

Askins, R. A., and D. N. Ewert. 1991. Impact of Hurricane Hugo on bird populations on 
St. John, U.S. Virgin Islands. Biotropica 23:481-487.

Barrett, P. H., and R. B. Freeman, eds. 1986. The works of Charles Darwin. Vol. 3, Journal of researches, part II. New York University Press, New York.

Bellingham, P. J., E. V. J. Tanner, and J. R. Healey. 1994. Sprouting of trees in Jamaican montane forests after a hurricane. J. Ecol. 82:747-758.

Burslem, D. F. R. P., T. C. Whitmore, and G. C. Brown. 2000. Short-term effects of cyclone impact and long-term recovery of tropical rain forest on Kolombangara, Solomon Islands. J. Ecol. 88:1063-1078.

Butler, D. J. 2004. Assessment of the impacts of Cyclone Heta on the terrestrial biodiversity of Niue. Department of Environment, Niue, and United Nations Development Programme, Apia, Samoa.

Cox, P. A., T. Elmqvist, E. D. Pierson, and W. E. Rainey. 1991. Flying foxes as strong interactors in South Pacific island ecosystems: A conservation hypothesis. Conserv. Biol. 5:448-454.

Craig, P., T. E. Morrell, and K. So'oto. 1994. Subsistence harvest of birds, fruit bats, and other game in American Samoa, 19901991. Pac. Sci. 48:344-352.

Dawson, D. G., and P. C. Bull. 1975. Counting birds in New Zealand forests. Notornis 22:101-109.

Esselstyn, J. A., A. Amar, and D. Janeke. 2006. Impact of post-typhoon hunting on Mariana fruit bats (Pteropus mariannus). Pac. Sci. 60:531-539.

Everham, E. M., and N. V. L. Brokaw. 1996. Forest damage and recovery from catastrophic wind. Bot. Rev. 62:113-185.

Feare, C., and A. Craig. 1999. Starlings and mynas. Christopher Helm Ltd., London.

Freifeld, H. B. 1999. Habitat relationships of forest birds on Tutuila Island, American Samoa. J. Biogeogr. 26:1191-1213.

Gibbs, D., E. Barnes, and J. Cox. 2001. Pigeons and doves: A guide to the pigeons and doves of the world. Pica Press, Sussex, United Kingdom.

James, R. E., and M. N. Clout. 1996. Nesting success of New Zealand pigeons (Hemiphaga novaeseelandiae) in response to a rat (Rattus rattus) poisoning programme at
Wenderholm Regional Park. N.Z. J. Ecol. 20:45-51.

Johnson, D. H. 1995. Statistical sirens: The allure of nonparametrics. Ecology 76:1998-2000.

Lane, J. 1994. Niue: State of the environment report 1993. South Pacific Regional Environment Programme, Apia, Western Samoa.

Lee, W. G., M. N. Clout, H. A. Robertson, and J. B. Wilson. 1991. Avian dispersers and fleshy fruits in New Zealand. Pages 1617-1623 in Acta 20th Congress of International Ornithology. New Zealand Ornithological Congress Trust Board, Wellington, New Zealand.

Lovegrove, T., B. Bell, and R. Hay. 1992. The indigenous wildlife of Western Samoa: Impacts of Cyclone $\mathrm{Val}$ and a recovery and management strategy. New Zealand Ministry of External Relations and Trade, Wellington.

Martell, F., T. Dewulf, and A. Atherton. 1997. Pilot community deforestation survey in the South Pacific: The cases of Western Samoa and Niue. United Nations Development Programme and South $\mathrm{Pa}-$ cific Regional Environment Programme, Apia, Samoa.

McConkey, K. R., and D. R. Drake. 2002. Extinct pigeons and declining bat populations: Are large seeds still being dispersed in the tropical Pacific? Pages 381-395 in D. J. Levey, W. R. Silva, and M. Galetti, eds. Seed dispersal and frugivory: Ecology, evolution and conservation. Commonwealth Agricultural Bureaux International, Wallingford, United Kingdom.

Powlesland, R. G., J. R. Hay, and M. H. Powlesland. 2000. Bird fauna of Niue Island in 1994-95. Notornis 47:39-53.

Prather, J. W., and K. G. Smith. 2003. Effects of tornado damage on forest bird populations in the Arkansas Ozarks. Southwest. Nat. 48:292-297.

Rainey, W. E., E. D. Pierson, T. Elmqvist, and P. A. Cox. 1995. The role of flying foxes (Pteropodidae) in oceanic island ecosystems of the Pacific. Symp. Zool. Soc. Lond. 67:47-62.

Richards, G. C. 1990. The spectacled flying fox, Pteropus conspicillatus (Chiroptera: 
Pteropodidae), in North Queensland. 2. Diet, seed dispersal, and feeding ecology. Aust. Mammal. 13:25-31.

Richmond-Rex, P., T. Cooper, J. Nemaia, and D. Butler, eds. 2001. National biodiversity strategy and action plan. Government of Niue, Alofi, Niue.

Robertson, H. A., and E. K. Saul. 2007. Conservation of kakerori (Pomarea dimidiata) in the Cook Islands in 2005/06. Department of Conservation Research and Development Series 285. New Zealand Department of Conservation, Wellington.

Schofield, J. C. 1959. The geology and hydrology of Niue Island, South Pacific. N. Z. Geol. Surv. Bull. 62. Government Printer, Wellington.

Shepherd, R. C. H. 2004. Pretty but poisonous: Plants poisonous to people: An illustrated guide for Australia. R. G. and F. J. Richardson, Melbourne.

Sinavaiana, C., and J. Enright. 1992. The cultural significance of the flying fox in Samoa: A legendary view. In $\mathrm{D}$. Wilson and G. Graham, eds. Pacific island flying foxes: Proceedings of an International Conference. U.S. Fish Wildl. Serv. Biol. Rep. 90:36-38.

Smith, S. P. 1902. Niue-Fekai (or Savage) Island and its people. Whitcome and Tombs, Wellington.

Steadman, D. W., and J. Franklin. 2000. A preliminary survey of landbirds on Lakeba, Lau Group, Fiji. Emu 100:227235.

Steadman, D. W., and H. B. Freifeld. 1998. Distribution, relative abundance, and habitat relationships of landbirds in the $\mathrm{Va}$ va'u Group, Kingdom of Tonga. Condor 100:609-628.

- 1999. The food habits of Polynesian pigeons and doves: A systematic and biogeographic review. Ecotropica 15:13-33.

Tejeda-Cruz, C., and W. J. Sutherland. 2005. Cloud forest bird responses to unusually severe storm damage. Biotropica 37:8895.

Torres, J. A. 1992. Lepidoptera outbreaks in response to successional changes after the passage of Hurricane Hugo in Puerto Rico. J. Trop. Ecol. 8:285-298.
Trenberth, K. 2005. Uncertainty in hurricanes and global warming. Science (Washington, D.C.) 308:1753-1754.

Varty, N. 1991. The status and conservation of Jamaica's threatened and endemic forest avifauna and their habitats following Hurricane Gilbert. Bird Conserv. Int. 1:135151.

Waide, R. B. 1991. The effect of Hurricane Hugo on bird populations in the Luquillo Experimental Forest, Puerto Rico. Biotropica 23:475-480.

Walter, R., and A. Anderson. 1995. Archaeology of Niue Island: Initial results. J. Polynesian Soc. 104:471-481.

Watling, D. 2001. A guide to the birds of Fiji and western Polynesia: Including American Samoa, Niue, Samoa, Tokelau, Tonga, Tuvalu and Wallis \& Futuna. Fiji Environmental Consultants, Suva, Fiji.

Wauer, R. H., and J. M. Wunderle Jr. 1992. The effect of Hurricane Hugo on bird populations on St. Croix, U.S. Virgin Islands. Wilson Bull. 104:656-673.

Webster, P. J., G. J. Holland, J. A. Curry, and H.-R. Chang. 2005. Changes in tropical cyclone number, duration, and intensity in a warming environment. Science (Washington, D.C.) 309:1844-1846.

Wiley, J. W., and J. M. Wunderle. 1993. The effects of hurricanes on birds, with special reference to Caribbean islands. Bird Conserv. Int. 3:319-349.

Wodzicki, K. 1971. The birds of Niue Island, South Pacific: An annotated checklist. Notornis 18:291-304.

Wolcott, G. N. 1932. The effect of the hurricane San Cyprian on insects in Puerto Rico. Insect Pest Surv. Bull. 12:409-410.

Wunderle, J. M., Jr. 1995. Responses of bird populations in a Puerto Rican forest to Hurricane Hugo: The first 18 months. Condor 97:879-896.

- 1999. Pre- and post-Hurricane fruit availability: Implications for Puerto Rican parrots in the Luquillo Mountains. Caribb. J. Sci. 35:249-264.

Wunderle, J. M., Jr., D. J. Lodge, and R. B. Waide. 1992. Short-term effects of Hurricane Gilbert on terrestrial bird populations on Jamaica. Auk 109:148-166. 
